Published in final edited form as:

Curr Opin Virol. 2015 August ; 13: 117-122. doi:10.1016/j.coviro.2015.06.003.

\title{
Animal Models of Respiratory Syncytial Virus Infection and Disease
}

\author{
Randy E. Sacco ${ }^{1}$, Russell K. Durbin ${ }^{2}$, and Joan E. Durbin ${ }^{2,3}$ \\ ${ }^{1}$ Ruminant Diseases and Immunology Research Unit, National Animal Disease Center, USDA, \\ Agricultural Research Service, Ames, IA \\ ${ }^{2}$ Center for Immunity and Inflammation, Rutgers, The State University of New Jersey, New Jersey \\ Medical School, Newark, NJ \\ ${ }^{3}$ Department of Pathology, Rutgers, The State University of New Jersey, New Jersey Medical \\ School, Newark, NJ
}

\begin{abstract}
The study of human respiratory syncytial virus pathogenesis and immunity has been hampered by its exquisite host specificity, and the difficulties encountered in adapting this virus to a murine host. The reasons for this obstacle are not well understood, but appear to reflect, at least in part, the inability of the virus to block the interferon response in any but the human host. This review addresses some of the issues encountered in mouse models of respiratory syncytial virus infection, and describes the advantages and disadvantages of alternative model systems.
\end{abstract}

\section{Introduction}

\begin{abstract}
Respiratory Syncytial Virus (RSV), a member of the paramyxovirus family, remains a major clinical problem for which there is no effective vaccine or treatment. This is a ubiquitous respiratory pathogen that infects $100 \%$ of humans by the age of 2 (23), and is the most common cause of lower respiratory tract infection in infants and young children (43). The most severe disease afflicts infants experiencing a primary infection. RSV infection in older children and adults generally produces a relatively mild illness limited to the upper respiratory tract, but infection can cause fatal pneumonia in immunocompromised hosts, a cohort that includes young infants with immature immune systems and the fragile elderly. Most interesting is the capacity of this virus for frequent reinfection of the human host (24), a phenomenon that is not well understood. Unlike other acute respiratory virus infections, the ability of RSV to reinfect human patients does not appear to be due to rapid virus evolution, a trait common to many RNA viruses. Although there is published evidence suggesting that circulating viral clades change with respect to predominance in a given population, there is no evidence of progressive viral evolution resulting in emergence of new
\end{abstract}

Corresponding author: Durbin, Joan E, (durbinje@njms.rutgers.edu).

Publisher's Disclaimer: This is a PDF file of an unedited manuscript that has been accepted for publication. As a service to our customers we are providing this early version of the manuscript. The manuscript will undergo copyediting, typesetting, and review of the resulting proof before it is published in its final citable form. Please note that during the production process errors may be discovered which could affect the content, and all legal disclaimers that apply to the journal pertain. 
strains (31). These observations are all the more interesting given that this virus has no known animal reservoir, and the source of the inevitable yearly epidemics is unclear.

\section{Rodent Models of RSV Infection}

This exquisite specificity of RSV for the human host has made it challenging to develop small animal models of RSV pathogenesis, and therefore difficult to understand the basis of the relatively ineffective human immune response to this infection. This dilemma has been a major hurdle for vaccine development, which has been unsuccessful despite a half century of intensive research. Cormier et al. (14) have estimated that $77 \%$ of published RSV studies have been carried out in mice, a species with well characterized genetics, for which a host of immunological techniques and reagents are available. Many important studies have been carried out in mouse models of RSV infection (recently reviewed by Openshaw (34)), but the limitations of this model leave open to question our ability to translate information gained by these studies into clinical practice.

A major issue in animal model development is the relative resistance of rodent species to human RSV infection. Although the commonly used BALB/c mouse has been shown be among the most susceptible mouse strains (45), inoculation of these mice with very large doses of virus produces minimal microscopic disease and a total viral yield on the order of 1000 -fold below virus input. The high degree to which RSV is adapted to its only natural host (Homo sapiens) presents a complicated challenge to the development and interpretation of animal models. Even in the phylogenetically most closely matched hosts - nonhuman primates - RSV replication and pathogenesis poorly reflects human RSV infections (3). Two approaches toward an improved mouse model have been contemplated: (1) adaptation of hRSV to nonhuman hosts, and (2) use of related cognate virus/host pairs. The first approach is exemplified by the adaptation multiple human pathogens to mice by serial passage, examples being influenza A virus (8), SARS (40), and ebolavirus. Adult mice are resistant to infection with strains of ebolavirus isolated from humans, though suckling mice are susceptible. Bray et al. (7) passaged virus through successively older mice and recovered, after six such cycles, a "mouse-adapted" ebolavirus. The key mutations accounting for virulence in mice were determined to be mutations that conferred resistance to the interferon response (17). Attempts to adapt hRSV to the mouse have not been successful. The very low ratio of progeny to inoculum virus in in vivo passage represents an insurmountable hurdle to this approach. We have passaged the virus in cultured mouse cells over hundreds of cycles and, despite the accumulation of genotypic and phenotypic (i.e. plaque morphology) changes, we have seen no apparent shift in the ability of the passaged virus to replicate in the mouse (unpublished data). Mice lacking signal transducer and activator of transcription 1 (STAT1), and therefore interferon responsiveness, are in fact more susceptible to hRSV (16) (See Figure 1), but even in this model the host can be described at best as "semipermissive" for RSV replication. The ratio of progeny to inoculum is still > 1/100. Thus there are likely mismatches between hRSV's innate immunity counterdefenses and corresponding molecular targets in mice, independent of STAT1 pathways. The RSV gene products that have been associated with inhibiting the interferon response are NS1 and NS2 (42**; 48). These proteins have been implicated in the accelerated degradation of STAT2 in human cells (18; 30) (critical in the response to type I and type III interferons) and in the inactivation of RIG- 
I, TRAF3 and IRF-3 (2) - all essential to the induction of both type I and type III interferons. The extent to which these viral products are "tuned" to their natural hosts was best demonstrated by Bossert \& Conzelmann $\left(5^{* *}\right)$, who constructed rhabdoviruses with either human or bovine RSV NS1 or NS2, and found the resistance of the resulting recombinant viruses to type I interferon was host specific, even for these closely related viruses.

A more permissive rodent model of RSV disease, and the species used with increasing frequency for testing RSV vaccines and therapeutics, is the cotton rat (Sigmodon hispidus) $\left(38^{*}\right)$, recently reviewed in detail by Boukhvalova et al. (6). In addition to the increased virus replication, respiratory tract infection in the cotton rat more closely resembles that seen in human subjects, with diffuse infection of the nasal mucosa, and replication limited to bronchiolar rather than alveolar mucosa as seen in the mouse lung. See Figure 2. Also similar to human patients, cotton rats are susceptible to reinfection of the upper airway beginning 8 months after primary infection (37). Unlike other new world rodents, such as guinea pigs, which have also been used for RSV studies, cotton rats are available as an inbred strain, and a growing number of reagents are available for the study of cytokines and chemokines in this species.

\section{Bovine RSV in Cattle}

The alternative approach to animal model development is to explore the utility of related cognate virus/host pairs. The only such pair involving rodents identified to date is pneumonia virus of mice (PVM). In this system - similar to infection of humans by hRSV a small inoculum produces orders of magnitude more progeny, and substantial pathogenesis (4). One severe drawback to this system, however, is the very remote relationship between PVM and hRSV (See Figure 3), rendering any extrapolations between distantly related gene products and their mechanisms tenuous. The pneumovirus most closely related hRSV is bovine RSV (bRSV) which was first isolated from calves in 1970 (26; 27; 36). Estimates of similarities at the nucleotide level by Elvander et al. (19) ranged from 38 and $41 \%$ while, in this same study, three hRSV strains exhibited genetic similarities of approximately $62 \%$. Bovine RSV is a naturally occurring infection in calves. Infection can be subclinical and involve the upper respiratory tract or both the upper and lower respiratory tree (50). Clinical signs can include tachypnea, oculonasal discharge, anorexia, reduced activity and fevers up to $40^{\circ} \mathrm{C}$. These signs coincide with bRSV replication, which is detectable as early as day 2 and continues until 7 to 10 days postinfection. Like hRSV, bRSV-associated disease is most severe in young calves less than 6 months of age, and infection can occur even in the presence of maternal antibodies. It has been estimated that more than $70 \%$ of calves have seroconverted by the age of 12 months. As with hRSV in children, re-infections in calves are common. Also like hRSV, seasonal periodicity is seen with bRSV in temperate climates, with most common occurrences of infections in the fall and winter months.

The bovine respiratory tract provides an excellent model system for the study human respiratory diseases. In the upper respiratory tract, bovine palatine and nasopharyngeal tonsils are similar to human tonsils (39), while no tonsils are present in any rodent species (9). The bovine and human trachea is lined by ciliated pseudostratified columnar epithelium, 
whereas in mice the majority of the tracheal surface is populated by non-ciliated epithelial cells. Airway submucosal glands are common in humans and ruminants (13), whereas the mouse has few, if any (28). It has been suggested that the relatively large airway lumen and lack of mucosal glands in mice may result in little compromise in lung function as a result of inflammatory processes, whereas this would not be the case in larger animals, including humans (28).

Experimental infection of calves with bRSV reproduces clinical signs seen in field cases, but these signs have been observed to vary in severity. This is likely dependent on variables such as the route of inoculation, dose, number of inoculations, and age of calves at challenge. We have used a bRSV aerosol challenge model adapted from that described by Woolums et al (51). Each calf receives a $5 \mathrm{ml}$ challenge inoculum containing approximately 104 TCID/50 ml. of bRSV during a nebulization period of 10-15 min (41). Following infection, bRSV replicates in upper respiratory tract epithelial cells and then spreads to the lower airways. Peak viral titers occur at day 7 , followed by a rapid decline with shedding detected for up to 10 days following challenge. Significant microscopic lesions are apparent with bronchioles filled with neutrophils and cell debris and surrounded by inflammatory cells and expansion of the interstitial spaces with edema fluid, macrophages and lymphocytes. As with human subjects, viral antigen staining is primarily restricted to cells lining the bronchiole. See Figure 3.

An adaptive immune response is required for the control and clearance of established RSV infections. Following infection, humans and cattle mount virus-specific antibody and $\mathrm{T}$ cell responses; however, these responses are weak and transient, as both species can be continuously re-infected throughout life. $\mathrm{T}$ cell responses are directed at epitopes within several bRSV proteins including the N, M, NS2, M2-1, F and G (32). Calves infected with bRSV develop a mixed cytokine response, but favor the development of a Th2-type immune response following infection. Studies of the cells and lymph fluid from bRSV infected calves reveal enhanced IL- 4 and IL-13 production in the serum and tissues as early as day 4 post infection, and increased serum levels of virus-specific IgE, indicating the establishment of a Th2-type response $(33 ; 46 ; 47)$. Prospective human studies have suggested that severe RSV disease in infancy may predispose to, or act as a marker for, the development of asthma later in life $(10 ; 11 ; 44)$. Interestingly, bRSV infection in calves has also been shown to predispose to allergic sensitization $(21 ; 22)$.

Severe RSV infection in human infants is associated with a significant influx of CD8 T cells into the airways (25), and calves infected with bRSV exhibit a similar increase of CD8 T cells in the lungs, trachea and nasopharynx (25). The HLA class I restricted response in human patients is primarily directed against the $\mathrm{M} 2, \mathrm{~F}$, and $\mathrm{N}$ proteins $(1 ; 12 ; 35)$, whereas, bovine CD8 T cells target the M2, F, N and G proteins of bRSV ( $20 * ; 49 * *)$. Interestingly, while G-specific CD8 T cells are readily detectable in cattle, they have not been demonstrated in human subjects. Humoral immunity also plays an important role in protection from RSV infection. While not completely effective, maternal antibodies may provide some level of protection from severe RSV infection in both human infants and calves $(15 ; 29 ; 52)$; however, their presence has also been described to suppress the development of antibody and $\mathrm{T}$ cell responses during acute infection. In addition to the 
extensive literature characterizing bRSV and the immune response to this virus in cattle, immunological studies in this species are made possible by the availability of hundreds of monoclonal antibodies to bovine cells surface molecules, cytokines and chemokines. The commercially available reagent list for cattle can be found at http://www.umass.edu/vetimm/ ruminants/index.html.

\section{Synthesis and Future Directions}

The choice of animal models must be based on many factors including expense and availability of methods and reagents. Nonetheless, consideration of additional factors, such as virus susceptibility and viral adaptation to host immune defenses also determines the usefulness of a given model for understanding mechanisms of viral pathogenesis and immunity in man. While the mouse model allows us the use of powerful genetic approaches, the inability to adapt this virus to growth in this species leaves open to question the relevance of mouse studies to human disease. The cotton rat is more susceptible, and provides a model of upper and lower airway infection, but relatively few tools are currently available for mechanistic studies in this species. Despite the practical difficulties of working with large animals, there are many reasons to suggest that a greater focus on understanding bRSV pathogenesis and immunity in cattle will yield more information that can be translated into improved strategies for hRSV treatment and vaccination than will studies in rodents. Foremost is our inability to adapt hRSV to rodent models, coupled with the very close relationship of hRSV and bRSV, and the similarity in viral pathogenesis, dynamics of virus spread, and apparent blocks to development of effective immunity between the human and bovine systems. If the exquisite host specificity of this pathogen cannot be overcome, it may be wise to study the basis of this adaptation using bRSV and its natural host. As with hRSV, effective bRSV vaccination has not yet been achieved, despite the major economic impact of this virus. With the longer lifespan of cattle relative to rodents, it should be possible to study the memory B and T cell populations responsive to RSV antigens over years rather than weeks, and the effects of experimental vaccine variables on those lifetimes.

\section{Acknowledgments}

RES, RKD and JED are funded by the National Institutes of Health (Grant number R01AI088770). JD also receives funds from New Jersey Medical School.

\section{References}

1. Bangham CRM, Openshaw PJM, Ball LA, King AMQ, Wertz GW, Askonas AB. Human and murine cytotoxic T cells specific to RSV recognize the viral nucleoprotein $(\mathrm{N})$, but not the major glycoprotein (G), expressed by vaccinia virus recombinants. J Immunol. 1986; 137:3973-3977. [PubMed: 2431051]

2. Barik S. Respiratory syncytial virus mechanisms to interfere with type 1 interferons. Curr Top Microbiol Immunol. 2013; 372:173-191. [PubMed: 24362690]

3. Belshe RB, Richardson LS, London WT, Sly DL, Lorfeld JH, Camargo E, Prevar DA, Chanock RM. Experimental respiratory syncytial virus infection of four species of primates. J Med Virol. 1977; 1:157-162. [PubMed: 416176]

4. Bonville CA, Bennett NJ, Koehnlein M, Haines DM, Ellis JA, DelVecchio AM, Rosenberg HF, Domachowske JB. Respiratory dysfunction and proinflammatory chemokines in the pneumonia virus of mice (PVM) model of viral bronchiolitis. Virology. 2006; 349:87-95. [PubMed: 16563455] 
5**. Bossert B, Conzelmann KK. Respiratory syncytial virus (RSV) nonstructural (NS) proteins as host range determinants: a chimeric bovine RSV with NS genes from human RSV is attenuated in interferon-competent bovine cells. J Virol. 2002; 76:4287-4293. Demonstrated that resistance to type I interferons via RSV NS1 and NS2 gene products is host specific. [PubMed: 11932394]

6. Boukhvalova MS, Blanco JC. The cotton rat Sigmodon hispidus model of respiratory syncytial virus infection. Curr Top Microbiol Immunol. 2013; 372:347-358. [PubMed: 24362698]

7. Bray M, Davis K, Geisbert T, Schmaljohn C, Huggins J. A mouse model for evaluation of prophylaxis and therapy of Ebola hemorrhagic fever. J Infect Dis. 1998; 178:651-661. [PubMed: 9728532]

8. Brown EG, Liu H, Kit LC, Baird S, Nesrallah M. Pattern of mutation in the genome of influenza A virus on adaptation to increased virulence in the mouse lung: identification of functional themes. Proceedings of the National Academy of Sciences of the United States of America. 2001; 98:68836888. [PubMed: 11371620]

9. Casteleyn C, Breugelmans S, Simoens P, Van den Broeck W. The tonsils revisited: review of the anatomical localization and histological characteristics of the tonsils of domestic and laboratory animals. Clinical \& developmental immunology. 2011; 2011:472460. [PubMed: 21869895]

10. Castro M, Schweiger T, Yin-Declue H, Ramkumar TP, Christie C, Zheng J, Cohen R, Schechtman KB, Strunk R, Bacharier LB. Cytokine response after severe respiratory syncytial virus bronchiolitis in early life. J Allergy Clin Immunol. 2008; 122:726-733. e723. [PubMed: 18760461]

11. Chawes BL, Poorisrisak P, Johnston SL, Bisgaard H. Neonatal bronchial hyperresponsiveness precedes acute severe viral bronchiolitis in infants. J Allergy Clin Immunol. 2012; 130:354-361. e353. [PubMed: 22713595]

12. Cherrie AH, Anderson K, Wertz GW, Openshaw PJM. Human cytotoxic T cells stimulated by antigen on dendritic cells recognize the $\mathrm{N}, \mathrm{SH}, \mathrm{F}, \mathrm{M}, 22 \mathrm{~K}$, and $1 \mathrm{~b}$ proteins of respiratory syncytial virus. J Virol. 1992; 66:2102-2110. [PubMed: 1548754]

13. Choi HK, Finkbeiner WE, Widdicombe JH. A comparative study of mammalian tracheal mucous glands. Journal of anatomy. 2000; 197(Pt 3):361-372. [PubMed: 11117623]

14. Cormier SA, You D, Honnegowda S. The use of a neonatal mouse model to study respiratory syncytial virus infections. Expert Rev Anti Infect Ther. 2010; 8:1371-1380. [PubMed: 21133663]

15. Crowe JE Jr, Williams JV. Immunology of viral respiratory tract infection in infancy. Paediatr Respir Rev. 2003; 4:112-119. [PubMed: 12758048]

16. Durbin JE, Johnson TR, Durbin RK, Mertz SE, Morotti RA, Peebles RS, Graham BS. The role of IFN in respiratory syncytial virus pathogenesis. J Immunol. 2002; 168:2944-2952. [PubMed: 11884466]

17. Ebihara H, Takada A, Kobasa D, Jones S, Neumann G, Theriault S, Bray M, Feldmann H, Kawaoka Y. Molecular determinants of Ebola virus virulence in mice. PLoS pathogens. 2006; 2:e73. [PubMed: 16848640]

18. Elliott J, Lynch OT, Suessmuth Y, Qian P, Boyd CR, Burrows JF, Buick R, Stevenson NJ, Touzelet O, Gadina M, Power UF, Johnston JA. Respiratory syncytial virus NS1 protein degrades STAT2 by using the Elongin-Cullin E3 ligase. J Virol. 2007; 81:3428-3436. [PubMed: 17251292]

19. Elvander M, Vilcek S, Baule C, Uttenthal A, Ballagi-Pordany A, Belak S. Genetic and antigenic analysis of the $\mathrm{G}$ attachment protein of bovine respiratory syncytial virus strains. J Gen Virol. 1998; 79 (Pt 12):2939-2946. [PubMed: 9880007]

20*. Gaddum RM, Cook RS, Furze JM, Ellis SA, Taylor G. Recognition of bovine respiratory syncytial virus proteins by bovine CD8+ T lymphocytes. Immunology. 2003; 108:220-229. Provided evidence for recognition of RSV G, F, N2 and M proteins by bovine CD8 T cells. [PubMed: 12562331]

21. Gershwin LJ, Anderson ML, Wang C, Berghaus LJ, Kenny TP, Gunther RA. Assessment of IgE response and cytokine gene expression in pulmonary efferent lymph collected after ovalbumin inhalation during experimental infection of calves with bovine respiratory syncytial virus. American journal of veterinary research. 2011; 72:134-145. [PubMed: 21194346] 
22. Gershwin LJ, Gunther RA, Hornof WJ, Larson RF. Effect of infection with bovine respiratory syncytial virus on pulmonary clearance of an inhaled antigen in calves. American journal of veterinary research. 2008; 69:416-422. [PubMed: 18312142]

23. Glezen WP, Paredes A, Allison JE, Taber LH, Frank AL. Risk of primary infection and reinfection with RSV. Am J Dis Child. 1986; 140:543-546. [PubMed: 3706232]

24. Hall C, Walsh E, Long C, Schnabel K. Immunity to and frequency of reinfection with respiratory syncytial virus. J Infect Dis. 1991; 163:693-698. [PubMed: 2010624]

25. Heidema J, Lukens MV, van Maren WW, van Dijk ME, Otten HG, van Vught AJ, van der Werff DB, van Gestel SJ, Semple MG, Smyth RL, Kimpen JL, van Bleek GM. CD8+ T cell responses in bronchoalveolar lavage fluid and peripheral blood mononuclear cells of infants with severe primary respiratory syncytial virus infections. J Immunol. 2007; 179:8410-8417. [PubMed: 18056387]

26. Inaba Y, Tanaka Y, Omori T, Matumoto M. Isolation of bovine respiratory syncytial virus. The Japanese journal of experimental medicine. 1970; 40:473-474. [PubMed: 5313158]

27. Inaba Y, Tanaka Y, Sato K, Ito H, Omori T. Nomi virus, a virus isolated from an apparently new epizootic respiratory disease of cattle. Japanese journal of microbiology. 1970; 14:246-248. [PubMed: 4988707]

28. Irvin CG, Bates JH. Measuring the lung function in the mouse: the challenge of size. Respir Res. 2003; 4:4. [PubMed: 12783622]

29. Kimman TG, Westenbrink F, Schreuder BE, Straver PJ. Local and systemic antibody response to bovine respiratory syncytial virus infection and reinfection in calves with and without maternal antibodies. J Clin Microbiol. 1987; 25:1097-1106. [PubMed: 2954996]

30. Lo MS, Brazas RM, Holtzman MJ. Respiratory syncytial virus nonstructural proteins NS1 and NS2 mediate inhibition of Stat2 expression and alpha/beta interferon responsiveness. J Virol. 2005; 79:9315-9319. [PubMed: 15994826]

31. Melero, JA.; Moore, ML. Influence of Respiratory Syncytial Virus Strain Differences on Pathogenesis and Immunity. In: Anderson, LJ.; Graham, BS., editors. Challenges and Opportunities for Respiratory Syncytial Virus. Berlin, Heidelberg: Springer;

32. Meyer G, Deplanche M, Schelcher F. Human and bovine respiratory syncytial virus vaccine research and development. Comparative immunology, microbiology and infectious diseases. 2008; 31:191-225.

33. Miao C, Woolums AR, Zarlenga DS, Brown CC, Brown JC Jr, Williams SM, Scott MA. Effects of a single intranasal dose of modified-live bovine respiratory syncytial virus vaccine on cytokine messenger RNA expression following viral challenge in calves. American journal of veterinary research. 2004; 65:725-733. [PubMed: 15198210]

34. Openshaw PJ. The mouse model of respiratory syncytial virus disease. Curr Top Microbiol Immunol. 2013; 372:359-369. [PubMed: 24362699]

35. Openshaw PJ, Anderson K, Wertz GW, Askonas BA. The 22,000-kilodalton protein of respiratory syncytial virus is a major target for Kd-restricted cytotoxic $\mathrm{T}$ lymphocytes from mice primed by infection. J Virol. 1990; 64:1683-1689. [PubMed: 2319650]

36. Paccaud MF, Jacquier C. A respiratory syncytial virus of bovine origin. Archiv fur die gesamte Virusforschung. 1970; 30:327-342. [PubMed: 4195627]

37. Prince G, Horswood R, Camargo E, Koenig D, Chanock R. Mechanisms of immunity to respiratory syncytial virus in cotton rats. Infect Immun. 1983; 42:81-87. [PubMed: 6352505]

38*. Prince GA, Jenson AB, Horswood RL, Camargo E, Chanock RM. The pathogenesis of respiratory syncytial virus infection in cotton rats. The American journal of pathology. 1978; 93:771-791. First description of the RSV infection model of the cotton rat strain currently available in the United States. [PubMed: 362946]

39. Rebelatto MC, Mead C, HogenEsch H. Lymphocyte populations and adhesion molecule expression in bovine tonsils. Veterinary immunology and immunopathology. 2000; 73:15-29. [PubMed: 10678395]

40. Roberts A, Deming D, Paddock CD, Cheng A, Yount B, Vogel L, Herman BD, Sheahan T, Heise M, Genrich GL, Zaki SR, Baric R, Subbarao K. A mouse-adapted SARS-coronavirus causes disease and mortality in BALB/c mice. PLoS pathogens. 2007; 3:e5. [PubMed: 17222058] 
41. Sacco RE, Nonnecke BJ, Palmer MV, Waters WR, Lippolis JD, Reinhardt TA. Differential expression of cytokines in response to respiratory syncytial virus infection of calves with high or low circulating 25-hydroxyvitamin D3. PloS one. 2012; 7:e33074. [PubMed: 22412984]

$42 * *$. Schlender J, Bossert B, Buchholz U, Conzelmann KK. Bovine respiratory syncytial virus nonstructural proteins NS1 and NS2 cooperatively antagonize alpha/beta interferon-induced antiviral response. J Virol. 2000; 74:8234-8242. First demonstration that NS1 and NS2 enhance virus growth by inhibiting the host interferon response. [PubMed: 10954520]

43. Shay DK, Holman RC, Newman RD, Liu LL, Stout JW, Anderson LJ. Bronchiolitis-associated hospitalizations among US children, 1980-1996. Jama. 1999; 282:1440-1446. [PubMed: 10535434]

44. Sigurs N, Bjarnason R, Sigurbergsson F, Kjellman B, Bjorksten B. Asthma and immunoglobulin E antibodies after respiratory syncytial virus bronchiolitis: a prospective cohort study with matched controls. Pediatrics. 1995; 95:500-505. [PubMed: 7700748]

45. Stark JM, McDowell SA, Koenigsknecht V, Prows DR, Leikauf JE, Le Vine AM, Leikauf GD. Genetic susceptibility to respiratory syncytial virus infection in inbred mice. J Med Virol. 2002; 67:92-100. [PubMed: 11920822]

46. Stewart RS, Gershwin LJ. Detection of IgE antibodies to bovine respiratory syncytial virus. Veterinary immunology and immunopathology. 1989; 20:313-323. [PubMed: 2718372]

47. Stewart RS, Gershwin LJ. Role of IgE in the pathogenesis of bovine respiratory syncytial virus in sequential infections in vaccinated and nonvaccinated calves. American journal of veterinary research. 1989; 50:349-355. [PubMed: 2930022]

48. Swedan S, Musiyenko A, Barik S. Respiratory syncytial virus nonstructural proteins decrease levels of multiple members of the cellular interferon pathways. J Virol. 2009; 83:9682-9693. [PubMed: 19625398]

49**. Taylor G, Thomas LH, Furze JM, Cook RS, Wyld SG, Lerch R, Hardy R, Wertz GW. Recombinant vaccinia viruses expressing the $F, G$ or N, but not the M2, protein of bovine respiratory syncytial virus (BRSV) induce resistance to BRSV challenge in the calf and protect against the development of pneumonic lesions. J Gen Virol. 1997; 78 (Pt 12):3195-3206. First study to delineate the involvement of individual RSV proteins for protection in a natural host. [PubMed: 9400970]

50. Valarcher JF, Taylor G. Bovine respiratory syncytial virus infection. Veterinary research. 2007; 38:153-180. [PubMed: 17257568]

51. Woolums AR, Anderson ML, Gunther RA, Schelegle ES, LaRochelle DR, Singer RS, Boyle GA, Friebertshauser KE, Gershwin LJ. Evaluation of severe disease induced by aerosol inoculation of calves with bovine respiratory syncytial virus. American journal of veterinary research. 1999; 60:473-480. [PubMed: 10211692]

52. Woolums AR, Gunther RA, McArthur-Vaughan K, Anderson ML, Omlor A, Boyle GA, Friebertshauser KE, McInturff PS, Gershwin LJ. Cytotoxic T lymphocyte activity and cytokine expression in calves vaccinated with formalin-inactivated bovine respiratory syncytial virus prior to challenge. Comparative immunology, microbiology and infectious diseases. 2004; $27: 57-74$. 


\section{Highlights}

Human RSV cannot be adapted to rodent species.

The pattern of infection seen in mice is unlike that found in the human host, infecting different cell types.

The cotton rat is a somewhat more permissive rodent model, susceptible to upper and lower airway disease as well as reinfection, similar to human subjects.

Bovine RSV is closely related to human RSV and produces a very similar disease in cattle. 

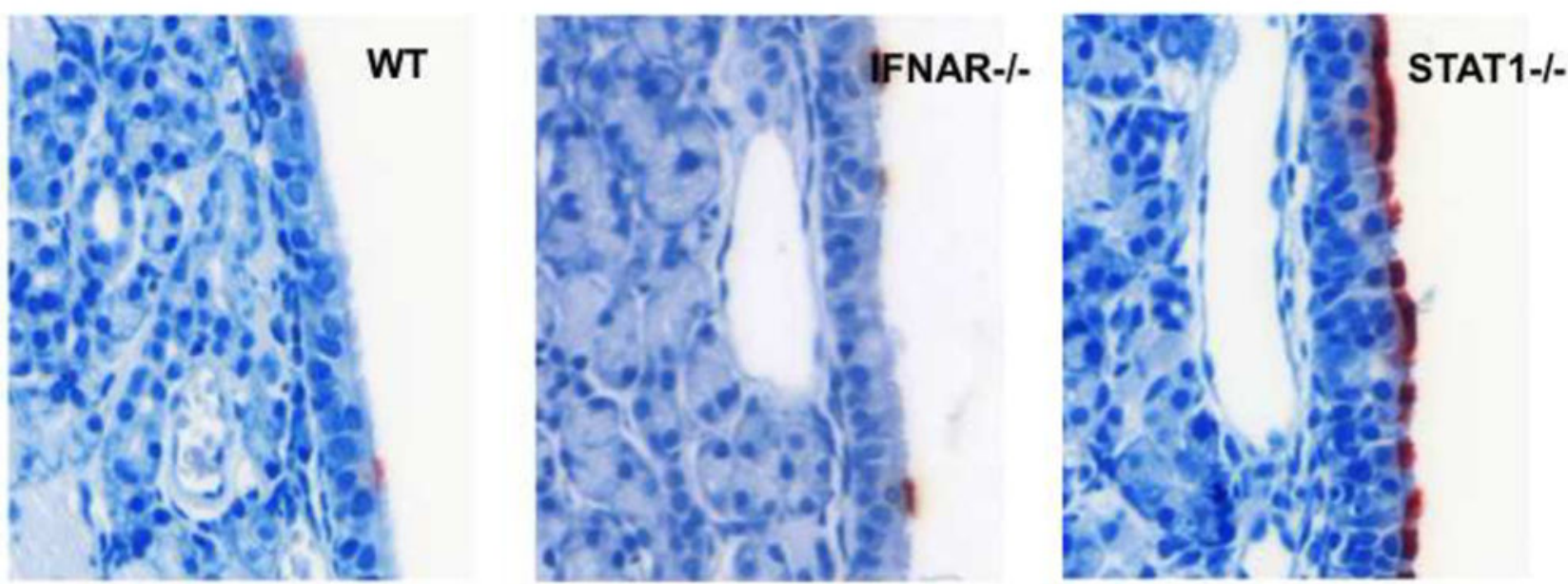

FIGURE 1.

In mice, the uppermost airway is resistant to hRSV infection. Photomicrographs taken here show the nasal septum four days after intranasal delivery of hRSV to wild type (WT) mice, or animals lacking the IFN- $\alpha / \beta$ Receptor chain 1 (IFNAR-/-), or the transcription factor Signal Transducer and Activator of Transcription 1 (STAT1-/-). The presence of viral proteins is demonstrated here by immunohistochemistry with RSV infected cells staining red. In WT or IFNAR-/- mice, only rare cells are infected, and infection appears not to spread to adjacent cells. The nasal respiratory mucosa in the STAT1-/- animals is relatively permissive, suggesting that IFN signaling restricts virus spread in this mouse. While IFNAR $-/-$ mice cannot respond to type I, or - $\alpha / \beta$ IFNs, the recently discovered type III, or $-\lambda$, IFNs also play a role in antiviral protection and are STAT1 dependent. 

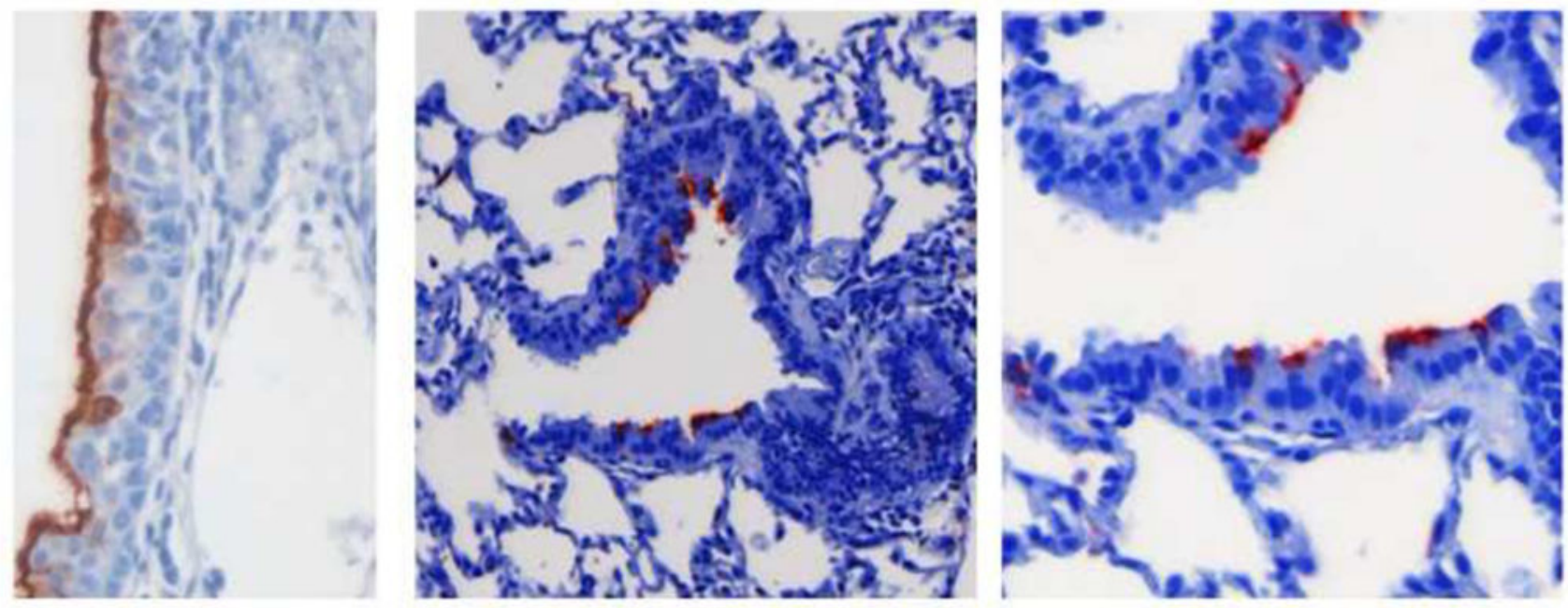

FIGURE 2.

In the cotton rat, the nasal cavity is susceptible to infection by hRSV, with diffuse immunostaining of the nasal mucosa (in red) as shown in the left hand panel. As with human patients, lower airway infection in the cotton rat involves the columnar epithelium lining the bronchioles, seen in the central and right hand panels. This is distinct from infection in the mouse model where it is primarily the alveolar lining cells that are infected by hRSV when lung sections are examined by immunohistochemistry. 


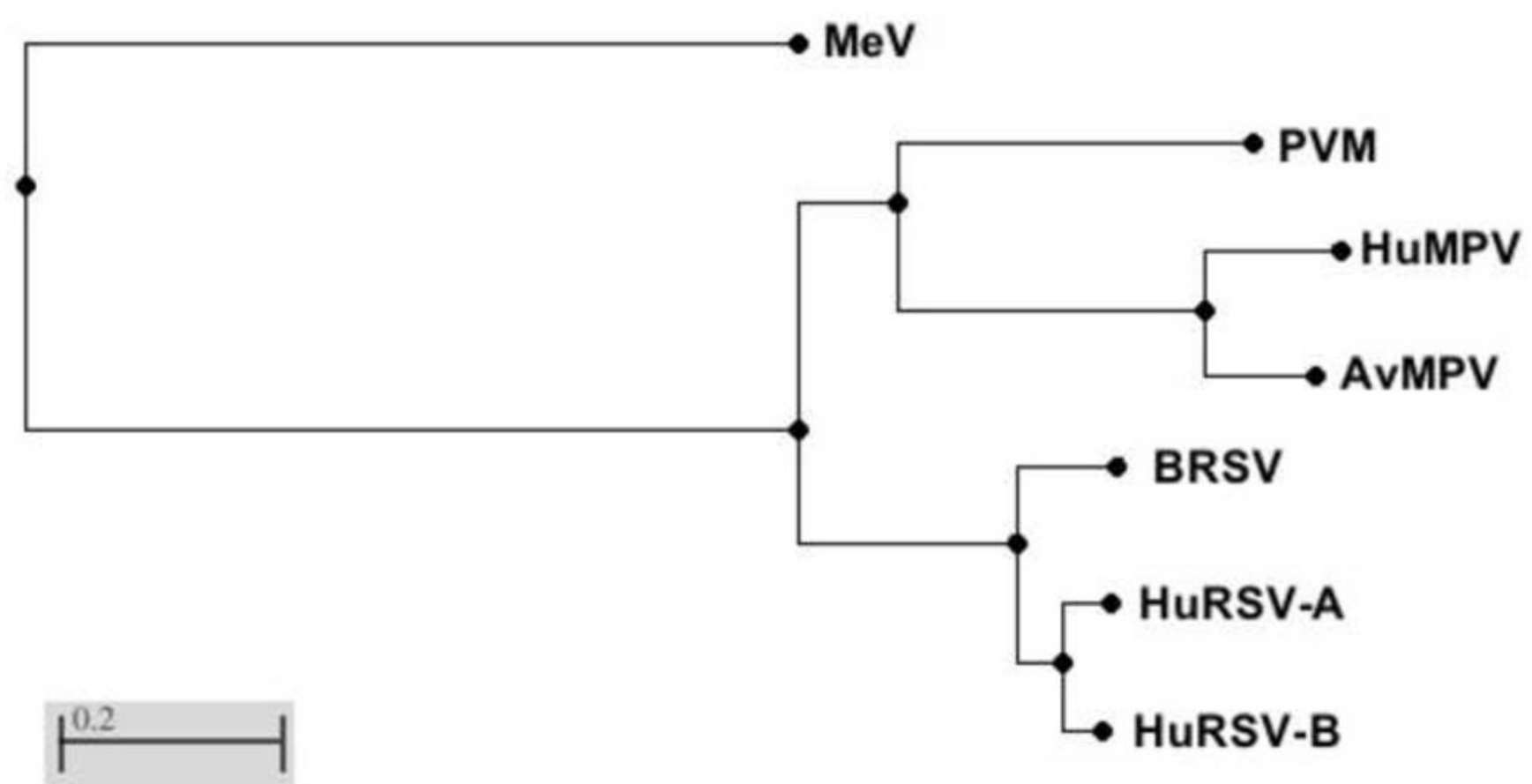

FIGURE 3.

Phylogenetic distances based on the amino acid sequences of the $\mathrm{L}$ (polymerase) protein. Sequences were aligned using BLAST (http://blast.ncbi.nlm.nih.gov/Blast.cgi).

Evolutionary distance is calculated by the method of Grishin \{Grishin, 1995 \#1138. Viruses (and Gen Bank accession numbers): MeV: measles virus (AAA75501), PVM: pneumonia virus of mice (AAW79184), HuMPV: human metapneumovirus (AHV79980), AvMPV: avian metapneumovirus (AAY82583), BRSV: bovine RSV (NP_048058), HuRSV-A: A subtype of human RSV (AEO45852), HuRSV-B: B subtype of human RSV (AEQ63655) 

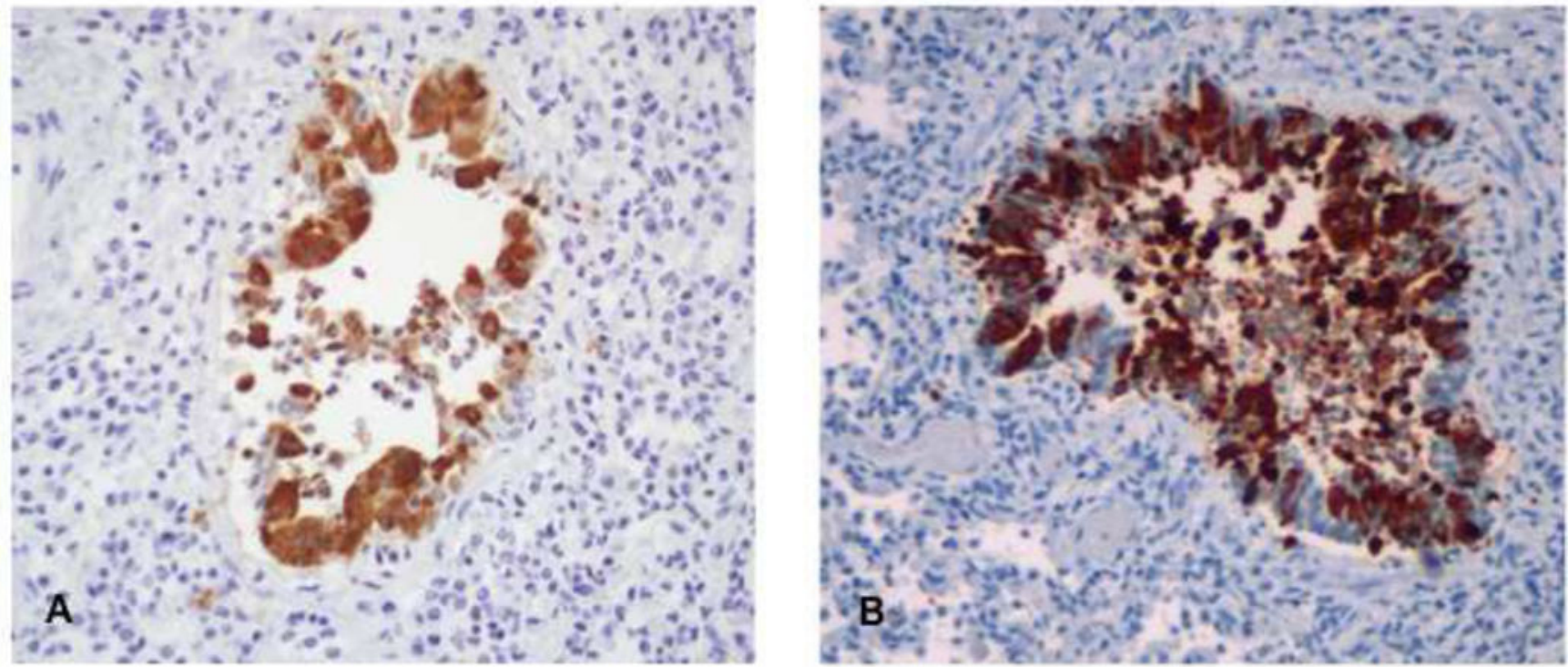

FIGURE 4.

Panel shows RSV infection of the ciliated respiratory epithelium of a calf bronchiole following experimental bRSV infection. Infected cells are brown in color. The infected bronchiole is surrounded by inflammatory cells, and neutrophils and necrotic cells are present in the airway lumen. The photomicrograph on the right is from the lung of an infant who died with hRSV. The pattern of infection shown here, also by immunohistochemistry, is similar showing the infection of the same ciliated, respiratory epithelial cell type. 